\title{
REVIEW: PENAMBAHAN MIKROENKAPSULASI MINYAK IKAN PADA PAKAN SEBAGAI INOVASI ENRICHMENT FEED UNTUK MENINGKATKAN PRODUKTIVITAS UNGGAS
}

\section{Review: The Microencapsulation of Fish Oil as a Feed Enrichment Innovation on Improving of Poultry Productivity}

\author{
Yuke Dorik Febrantama ${ }^{1}$, Muhamad Imam Hambali' ${ }^{1}$, Abigeil Akbar ${ }^{1}$, dan Niati Ningsih ${ }^{1}$ \\ ${ }^{1}$ Program Studi Manajemen Bisnis Unggas, Jurusan Peternakan, Politeknik Negeri Jember \\ E-mail: niatiningsih@polije.ac.id
}

\begin{abstract}
ABSTRAK
Mikroenkapsulasi minyak ikan merupakan teknik untuk melapisi komponen asam lemak esensial pada minyak ikan dengan menggunakan bahan pelapis tertentu. Fungsi teknik mikroenkapsulasi adalah untuk menjaga dan melindungi kestabilan komponen penting dalam minyak ikan agar dapat dimanfaatkan oleh tubuh ternak. Tujuan dari penulisan artikel review ini adalah untuk mengetahui teknik mikroenkasulasi pada minyak ikan sebagai inovasi enrichment feed dan pengaruhnya terhadap produktivitas unggas. Minyak ikan adalah bahan pakan sumber lemak esensial yang dibutuhkan ternak, akan tetapi dalam penggunaanya mudah teroksidasi oleh pengaruh lingkungan sehingga memiliki stabilitas umur simpan yang pendek dan kualitas yang cepat menurun. Penggunaan mikroenkapsulasi minyak ikan telah dilakukan pada beberapa unggas seperti puyuh, broiler dan layer. Penggunaan mikroenkapsulasi minyak ikan pada pakan dilaporkan dapat meningkatkan produktivias dan menurunkan kandungan kolesterol pada daging ayam broiler, serta meningkatkan kandungan asam lemak omega 3 dan menurunkan kandungan kolesterol pada kuning telur. Pemanfatan teknik mikroenkapsulasi minyak ikan pada pakan unggas masih jarang dilakukan sehingga perlu dikaji lebih dalam agar dapat dikembangkan untuk meningkatkan produktivitas unggas dan juga meningkatkan kualitas dari produk peternakan.
\end{abstract}

Kata kunci: Mikroenkapsulasi, Minyak Ikan, Produktivitas, Unggas

\begin{abstract}
Microencapsulation of fish oil is a technique to coat essential fatty acids content of fish oil with microencapsulating agent. This method is aimed to maintain the stability and protect essential fatty acids content of fish oil from deterioration thus can optimally utilized by the poultry. The objective of this review is to present microencapsulation fis oil methods as feed enrichments and their effect on poultry production. Fish oil is one of a major source of important fatty acids for poultry as well as a source of energy. However, it is prone to oxidation due to environmental changes thereby it has a short of storage stability because of decreasing the quality. Recently, the use of fish oil microencapsulation in poultry feed is a common practice such as in broiler, layer, and quails because it is known to have many beneficial effects at improving productivity and product quality. Most of present literature suggested that the use of microencapsulated fish oil increase broiler productivity and decrease cholesterol content in the broiler meat, improve omega 3 fatty acids content and decrease cholesterol content on the yolk. Since there is limited report of fish oil microencapsulations study, investigation of its effect on poultry production focusing on meat and egg quality as well as their overall performance is demanding for future direction.
\end{abstract}

Keywords: Microencapsulation, Fish Oil, Productivity, Poultry 


\section{PENDAHULUAN}

Minyak ikan merupakan sumber asam lemak yang kaya akan omega 3. Omega 3 merupakan konfigurasi asam lemak yang memiliki posisi ikatan rangkap pertama pada atom karbon nomor 3 dari ujung gugus metilnya (Idrus, 2013). Asam lemak esensial yang termasuk dalam kelompok asam lemak omega-3 adalah $\alpha$-linolenat (ALA), Asam Eikosa-pentaenoat (EPA), dan Asam Docosaheksaenoat (DHA) (Khamidah, et al., 2019). Asam lemak omega 3 adalah asam lemak rantai panjang atau Polyunstaurated fatty acids (PUFAs) yang mempunyai kemampuan untuk menurunkan kadar trigliserida dan kolesterol dalam darah, penting untuk perkembangan myocardium, otak dan retina, serta merupakan komponen penting dalam pertumbuhan dan perkembangan jaringan tubuh (Ellulu, et al., 2015). Kandungan omega 3 yang tinggi pada minyak ikan dapat dimanfaatkan untuk meningkatkan kualitas pakan melalui enrichment feed sehingga dapat menghasilkan produk peternakan yang menjadi bahan pangan fungsional karena mengandung tinggi omega 3. Terlebih lagi saat masa pandemi seperti sekarang ini, imun tubuh harus selalu bagus, agar terhindar dari berbagai penyakit. Salah satu cara untuk menjaga dan meningkatkan imunitas tubuh ialah dengan mengkonsumsi makanan yang bernutrisi.

Kandungan asam lemak tidak jenuh yang tinggi merupakan penyebab utama tingkat kerusakan pada minyak ikan, seperti mudah teroksidasi jika terpapar oksigen, sehingga menjadi tengik dan daya simpan menurun (Khamidah, et al., 2019). Penambahan minyak ikan pada pakan unggas dilakukan sebagai sumber energi dalam penyusunan ransum dan juga untuk mendapatkan produk ternak yang tinggi kandungan asam lemak omega-3 (Malvin, 2017). Pemberian minyak ikan secara langsung ke dalam pakan memiliki beberapa kendala yaitu pencampuran minyak ikan secara langsung dalam pakan dapat menyebabkan penggumpalan sehingga sulit untuk homogen, selain itu minyak ikan dalam bentuk cair sulit penanganannya, terutama dalam pendistribusian dan penyimpanan, karena minyak ikan tersebut mudah teroksidasi. Asam lemak omega 3 mudah teroksidasi oleh adanya oksigen di udara dan sinar ultra violet (UV) yang memiliki panjang gelombang pendek dan energi besar sehingga mudah memutuskan ikatan rangkap asam lemak menjadi tidak jenuh atau berada dalam bentuk radikal (Sestilawarti et al., 2013). Untuk itu perlu dilakukan suatu upaya perlindungan asam lemak omega 3 pada minyak ikan, salah satu cara yang dapat dilakukan adalah dengan melakukan teknik mikroenkapsulasi. Pemberian mikroenkapsulasi minyak ikan pada pakan dapat mempertahankan kualitas minyak ikan sehingga penggunaannya lebih efektif dan tepat sasaran.

Mikroenkapsulasi merupakan teknologi yang telah digunakan sejak kurang lebih 50 tahun di bidang farmasi, nutrisi dan biologi. Berdasarkan istilahnya, mikroenkapsulasi berarti suatu teknik enkapsulasi untuk melindungi komponen fungsional menggunakan material yang memiliki sifat barrier tinggi untuk menghasilkan mikrokapsul dengan ukuran 0,2 - $5000 \mu \mathrm{m}$ (Purnamayati, et al., 2016). Mikroenkapsulasi berguna untuk melindungi bioaktif dari minyak yang berbentuk cair menjadi bubuk padatan, sehingga memudahkan distribusi dan aplikasinya untuk fortifikasi makanan maupun obat-obatan (Wati \& Sriwidodo, 2020). Tujuan dari proses mikroenkapsulasi yaitu untuk meningkatkan kestabilan dan daya larut suatu bahan, untuk mengendalikan pelepasan senyawa aktif, untuk menghasilkan partikel-partikel padatan yang dilapisi oleh bahan penyalut tertentu dan meminimalisir kehilangan nutrisi. Mikroenkapulasi merupakan proses yang mengubah komponen dari bentuk minyak menjadi bentuk padat yaitu droplet kecil (Idrus, 2013). Minyak akan diperangkap oleh matrik kering suatu protein atau karbohidrat sebagai bahan pelapis yang berguna sebagai pengikat komponen penting dari minyak ikan.

Penelitian terkait aplikasi mikroenkapsulasi minyak ikan pada pakan telah dilakukan pada beberapa jenis unggas di antaranya adalah broiler, layer, dan puyuh. Malvin (2017) melaporkan 
penggunaan mikrokapsul minyak ikan hingga taraf 2\% dalam ransum ayam broiler dapat menurunkan kandungan kolesterol pada daging ayam broiler. Montesqrit (2007) melaporkan bahwa pemberian mikroenkapsulasi minyak ikan sebesar 4\% dalam ransum ayam petelur dapat meningkatkan kandungan asam lemak omega 3 pada kuning telur. Tujuan dari penulisan artikel ini adalah untuk melakukan review tentang teknik mikroenkasulasi pada minyak ikan, komponen bahan pelapis dalam proses mikroenkapsulasi, dan beberapa penelitian terkait penggunaan mikroenkapsulasi minyak ikan sebagai inovasi enrichment feed untuk meningkatkan produktivitas unggas.

\section{MATERI DAN METODE}

\section{Sumber Literatur Review}

Sumber literatur yang digunakan dalam penulisan artikel review ini adalah beberapa artikel yang merupakan hasil penelitian atau teori dasar yang telah dipublikasikan pada jurnal nasional dan internasional, makalah prosiding dan e book.

\section{Prosedur Penyusunan Artikel Review}

Proses penyusunan artikel review ini dilakukan melalui beberapa tahapan yaitu: Tahapan pertama merupakan tahap persiapan yang dilakukan dengan mengumpulkan dan membaca jurnal, makalah prosiding, buku yang diperoleh dari hasil pencarian. Selanjutnya memilih dan menentukan jurnal hasil penelitian, makalah ilmiah pada prosiding, buku terkait dengan topik yang sudah ditentukan. Tahapan ke dua yaitu penyusunan outline artikel yang akan ditulis. Pada tahapan ini menentukan skema berpikir terkait dengan topik yang akan di bahas. Tahapan ke tiga yaitu mengembangkan kerangka pemikiran dalam penyusunan makalah dengan menggunakan informasi ilmiah, teori, hasil penelitian yang diperoleh dari pustaka yang sudah diperoleh sebelumnya untuk kemudian dibuat menjadi sebuah makalah ilmiah. Tahapan ke empat yaitu pemeriksaan terhadap isi makalah yang sudah ditulis, baik secara substansi maupun redaksional.

\section{HASIL DAN PEMBAHASAN}

\section{Pengertian dan Teknik Mikroenkapsulasi}

Mikroenkapsulasi adalah proses fisik dimana bahan aktif (bahan inti), seperti partikel padatan, tetesan air ataupun gas, dikemas dalam bahan sekunder (dinding), berupa lapisan film tipis. Proses ini digunakan untuk melindungi suatu zat agar tetap tersimpan dalam keadaan baik dan untuk melepaskan zat tersebut pada kondisi tertentu saat dibutuhkan (Hidayah, 2016). Tujuan dari mikroenkapsulasi yaitu melindungi komponen penting minyak ikan dari pengaruh lingkungan, meningkatkan kestabilan dan daya larut minyak ikan dalam sistem pencernaan unggas, dan menghasilkan partikel padat yang terlindungi. Tipe mikroenkapsulasi secara umum ada dua yaitu satu inti (single core) dan banyak inti (multiple core) pada bagian dindingnya. Mikrokapsul dengan banyak inti memiliki inti yang tersebar secara merata di bagian dinding dan bagian tengah mikrokapsul biasanya berupa rongga kosong yang dihasilkan dari pemuaian selama tahap pengeringan akhir. Mikrokapsul dengan satu inti biasanya memiliki muatan inti yang tinggi, misalnya 90\% dari total berat mikrokapsul, sedangkan mikrokapsul dengan struktur banyak inti biasanya memiliki persentasi pelapis hingga 70\% dari berat mikrokapsul. Bahan pelapis ini akan rusak secara mekanik (pengunyahan, pemanasan, dan pelarut), perubahan $\mathrm{pH}$, enzim, serta sifat fisik dan kimia dari bahan inti (kelarutan, difusivitas, tekanan uap, dan koefisien partisi) dan juga sifat dari bahan 
pelapis (seperti ketebalan, porositas dan kemampuan bereaksi) sehingga bahan inti akan terlepas. Gambar mikroenkapsulasi single dan multiple core ditampilkan pada Gambar 1.

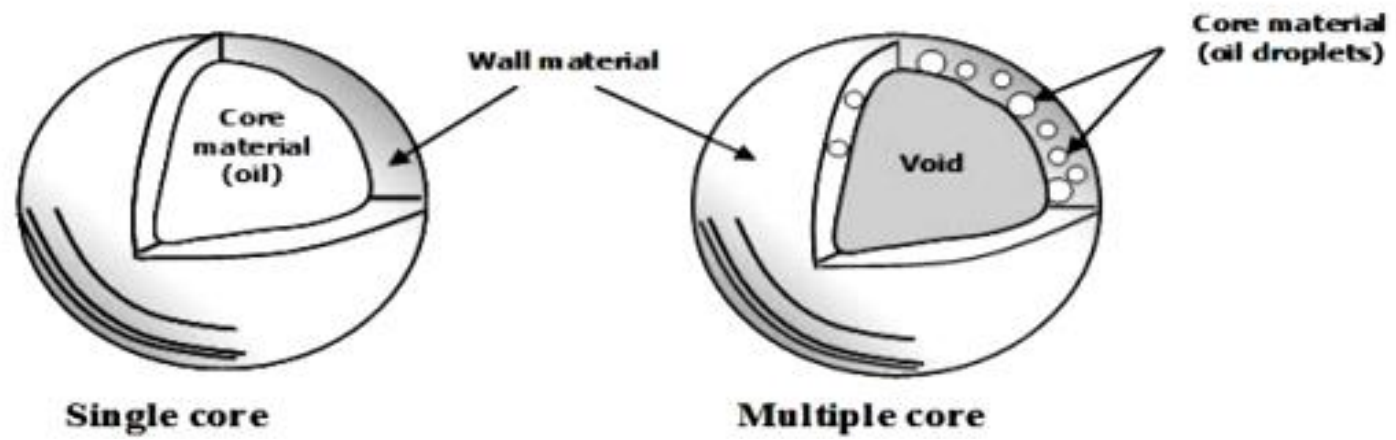

Gambar 1. Mikroenkapsulasi Single dan Multiple Core (Hidayah, 2016)

Metode Mikroenkapsulasi terbagi menjadi dua kelompok yaitu mikroenkapsulasi dengan metode fisik/mekanik (spray drying, spray chilling/cooling, extrusion, dan fluidized bed coating), dan proses kimia (coacervation, co-crystallization, molecular inclusion, dan interfacial or in-situ polymerization). Kombinasi kedua proses tersebut digunakan dalam pembentukan single atau double emulsi dengan metode spray drying (Madene,2006). Olive (2009) menjelaskan bahwa teknologi mikroenkapsulasi yang dapat digunakan dalam melindungi lemak dan protein antara lain freeze drying, spray drying, spray chilling/cooling, fluidized bed coating, coacervation, dan liposom entrapment.

Metode mikroenkapsulasi untuk minyak ikan sebagian besar dilakukan dengan menggunakan metode spray drying karena lebih efektif, fleksibel, dan efisien, serta dapat menghasilkan produk mikroenkapsulan dalam bentuk bubuk yang berkualitas baik (Idrus, 2013). Spray drying adalah teknik mikroenkapsulasi yang banyak dilakukan pada industri pangan, teknik ini mudah dan membutuhkan biaya yang lebih murah dibandingkan dengan teknik mikroenkapsulasi lainnya. Spray drying adalah proses mikroenkapsulasi dengan mengubah partikel dari bentuk cair menjadi padat berupa bubuk halus dengan menggunakan teknik penyemprotan dalam media panas (Kolanowski, et al., 2005). Spray drying dapat digunakan pada bahan yang labil terhadap panas, kemudian akan disalut dan diubah menjadi bentuk bubuk dengan stabilitas yang tinggi serta memiliki ukuran partikel yang kecil. Hasil produk mikroenkapsulasi menggunakan metode spray drying dipengaruhi oleh beberapa faktor diantaranya adalah desain spray dryer, bahan penyalut dan bahan pengemulsi, serta ketepatan setiap tahapan dalam proses mikroenkapsulasi (Khamidah, et al., 2019).

Spray drying merupakan teknik mikroenkapsulasi yang paling tua yang biasanya digunakan untuk bahan yang mengadung minyak, dan komponen bioaktif lain yang dapat berfungsi sebagai antioksidan. Komponen bahan penyalut yang bisanya digunakan dalam metode spray drying adalah maltodekstrin, gum arabic, dan pati. Polisakarida seperti alginat, gum, dan protein seperti natrium kaseinat, protein kedelai, dan protein whey juga dapat digunakan dalam proses enkapsulasi (Temiz \& Öztürk, 2018). Proses mikroenkapsulasi dengan menggunakan teknik spray drying terdiri dari dua tahapan yang pertama adalah proses emulsifikasi dan kedua adalah atomisasi. Faktor penting yang menentukan efisiensi enkapsulasi yang dihasilkan dalam teknik spray drying adalah karakteristik emulsi termasuk kestabilan bahan dan proses enkapsulasi termasuk rata - rata alir, temperatur inlet/outlet, dan kecepatan aliran gas. Proses atomisasi akan membentuk partikel dengan ukuran 1 - 10 mikron. Proses pengeringan dilakukan dengan menggunakan temperatur yang relatif tinggi, untuk inlet bisa mencapai $210^{\circ} \mathrm{C}$ dan outlet $90^{\circ} \mathrm{C}$ (Hasibuan, et al., 2017). 


\section{Bahan - Bahan Enkapsulan}

Bahan penyalut merupakan salah satu komponen penting dalam pembuatan mikroenkapsulasi minyak ikan. Dinding kapsul merupakan matriks polimer yang berasal dari beberapa komponen bahan yang terdispersi secara homogen. Fungsi dari bahan penyalut adalah untuk mengendalikan pelepasan senyawa inti yang dilindungi, membuat senyawa aktif lebih aman, menjaga dan melindungi kerusakan dari pengaruh lingkungan, melindungi efek dari cahaya, kelembaban, ataupun oksigen (Nugraheni et al., 2015). (Purnamayati et al., 2016) menambahkan bahwa bahan penyalut yang digunakan dalam proses mikroenkapsulasi harus dapat berperan sebagai emulsifier, dapat membentuk lapisan film, serta dapat membuat bahan aktif menjadi a free flowing powder, sehingga mudah ditambahkan dalam bahan pakan.

Bahan penyalut yang akan digunakan untuk proses enkapsulasi harus memiliki sifat aman untuk dikonsumsi unggas, tidak beracun, dan tidak bereaksi dengan komponen inti yang dienkapsulasi. Jenis bahan penyalut yang digunakan akan menentukan proses release bahan enkapsulan dalam tubuh unggas. Bahan penyalut yang digunakan dalam proses enkpasulasi dapat berasal dari satu jenis bahan atau dapat juga berasal dari kombinasi beberapa bahan yang berbeda. Hal tersebut disesuaikan dengan karakteristik sifat dari mikroenkapsulasi yang akan dibuat, kestabilan mikrokapsul, jenis bahan inti yang akan dilindungi, dan metode enkapsulasi yang akan digunakan. Formulasi penyalut dapat dikembangkan dari berbagai bahan penyalut, pengubah (modifiers), dan pelarut (Jayanudin \& Rochmadi, 2017).

Bahan penyalut yang sering digunakan adalah golongan gum, karbohidrat, dan protein (Khasanah, et al., 2015). Salah satu contoh bahan penyalut karbohidrat adalah pati dan maltodextrin. Bahan tersebut merupakan bahan penyalut yang memiliki nilai viskositas yang rendah pada padatan tinggi serta miliki nilai kelarutan yang tinggi. Kekurangan dari kedua bahan tersebut adalah rendahnya kemampuan untuk mengemulsi bahan inti yang berupa lemak, sehingga tidak dapat digunakan sebagai bahan penyalut tunggal, akan tetapi harus dikombinasikan dengan bahan penyalut yang memiliki kandungan protein serta yang memiliki sifat sebagai emulsifier. Bahan penyalut protein terdiri dari susu skim, whey, dan juga isolat protein kedelai. Bahan penyalut dari protein dapat mengikat komponen flavor, serta dapat menghasilkan mikrokapsul dengan rendemen, dan surface oil yang lebih tinggi (Nasrullah, 2010). Gum arab merupakan bahan penyalut yang berfungsi sebagai emulsifier, karena memiliki kemampuan untuk menghasilkan emulsi yang stabil. Penggunaan gum arab sebagai bahan enkapsulasi dapat memberikan perlindungan kepada senyawa inti yang bersifat volatil dari oksidasi dan penguapan (Kanakdande et al., 2007).

Bahan penyalut yang biasanya digunakan untuk mikroenkapsulasi minyak ikan dengan teknik spray drying adalah maltodektrin dan gum arab. Maltodextrin merupakan salah satu bahan penyalut yang berasal dari hasil hidrolisis pati menggunakan enzim atau asam dan mengandung senyawa $\alpha$ D-glukosa yang terikat dengan ikatan 1,4 glikosidik dan memiliki nilai dextrose equivalent (DE) kurang dari 20. Maltodextrin memiliki daya perlindungan rendah karena tidak mempunyai sifat lipofilik, untuk itu harus dikombinasikan dengan bahan lain (Khamidah, et al., 2019). Maltodextrin potensial untuk digunakan sebagai bahan penyalut karena harganya murah, tidak memiliki rasa yang kuat sehingga tidak mempengaruhi komponen inti, daya larut tinggi, dan melindungi komponen inti dari oksidasi. Maltodextrin telah banyak digunakan sebagai bahan pelapis minyak dan telah terbukti dapat melindungi komponen minyak dari oksidasi dan juga kerusakan akibat dari faktor external (Mohammed, et al., 2020).

Maltodextrin dikelompokkan berdasarkan kandungan dextrose equivalent (DE) yang merupakan derajat hidrolisis molekul pati. Maltodextrin dengan nilai DE 10, 20, dan 30 memiliki sifat fisik yang baik sebagai bahan palapis. Sebagai bahan enkapsulan maltodextrin biasanya dikombinasikan dengan gum arab (Mohammed, et al., 2020). Kombinasi bahan penyalut gum arab 
dan maltodekstrin lebih efektif untuk melindungi komponen bioaktif dibandingkan dengan bahan penyalut lainnya. Gum arab memiliki kemampuan retensi yang tinggi dengan sifat emulsifikasi yang baik sedangkan maltodekstrin tidak memiliki kemampuan emulsifikasi namun dapat menurunkan viskositas emulsi dan memiliki ketahanan oksidasi yang tinggi (Desmawarni, 2007).

Gum arab telah banyak digunakan untuk melapisi bahan inti berupa minyak. Gum arab adalah getah yang dihasilkan dari pohon akasia yang merupakan polimer dari asam d-glukuronat, Lrhamnose, d-galaktosa, dan L-arabinosa, dengan kandungan protein kurang lebih 2\%. Gum arab telah banyak digunakan untuk melapisi beberapa minyak seperti minyak ikan, minyak biji kenaf, dan minyak sawit (Mohammed, et al., 2020). Gum arab memiliki gugus arabinogalactan protein (AGP) dan glikoprotein (GP) sehingga memiliki kemampuan sebagai bahan pelapis yang berperan sebagai pengemulsi dan pengental (Idrus, 2013). Sebagai bahan pelapis, gum arab dapat berperan sebagai pembentuk tekstur, pembentuk film, pengikat dan juga pengemulsi yang baik dengan adanya komponen protein di dalam gum arab. Gum arab dapat dikeringkan dengan metode spray drying tanpa merusak komponen inti karena gum ini dapat membentuk lapisan yang dapat melindungi dari proses perubahan dekstruktif. Kekurangan dari penggunaan gum arab sebagai bahan pelapis adalah harganya yang cukup mahal dan ketersediaannya terbatas serta ketahanan oksidasinya rendah (Desmawarni, 2007).

\section{Aplikasi Mikroenkapsulasi Minyak Ikan Pada Unggas}

Minyak ikan merupakan bahan pakan sumber energi untuk unggas, selain itu minyak ikan juga merupakan sumber asam lemak esensial yang murah dan mudah untuk didapatkan. Minyak ikan juga dapat membantu proses absorsi vitamin yang larut dalam lemak serta meningkatkan palatabilitas pada pakan (Heldini, 2015). Minyak ikan mengandung asam lemak tak jenuh dengan konfigurasi omega-3. Beberapa asam lemak esensial yang termasuk dalam golongan omega 3 adalah Asam Linolenat (ALA), Asam Eikosapentaenoat (EPA), dan Asam Docosaheksaenoat (DHA). Penambahan minyak ikan dalam pakan juga dapat menjadi enrichment feed untuk menghasilkan produk peternakan yang kaya omega 3 (Malvin, 2017). Tingginya kandungan asam lemak esensial pada minyak ikan menjadikan minyak ikan mudah teroksidasi dengan adanya oksigen, perubahan kondisi lingkungan, dan adanya sinar ultra violet (UV) yang memiliki panjang gelombang pendek serta energi yang besar sehingga dapat memutuskan ikatan rangkap asam lemak dari jenuh menjadi tidak jenuh atau bahkan menjadi bentuk radikal bebas.

Lemak ikan yang telah teroksidasi memiliki kualitas yang menurun yang dapat dilihat dari perubahan warna serta adanya bau tengik pada minyak ikan (Idrus, 2013). Penambahan minyak ikan secara langsung ke dalam pakan unggas juga memiliki beberapa masalah diantaranya adalah pencampuran minyak ikan dalam bentuk cair sulit dilakukan karena akan menyebabkan penggumpalan pada pakan sehingga pakan sulit dihomogenkan. Penyimpanan dan pendistribusian minyak ikan dalam bentuk cair juga sulit untuk dilakukan (Malvin, 2017). Salah satu upaya yang dapat dilakukan untuk menjaga dan melindungi kestabilan komponen asam lemak omega 3, serta memudahkan penanganan dan pencampuran minyak ikan dalam pakan adalah dengan melakukan mikroenkapsulasi minyak ikan (Khamidah, et al., 2019; Malvin, 2017; Idrus, 2013)

Penggunaan mikroenkapsulasi minyak ikan sebagai tambahan pakan pada unggas telah dilakukan pada broiler, layer, juga pada puyuh. Malvin (2017) telah melakukan penelitian dengan menambahkan mikroenkapsulasi minyak ikan untuk ayam broiler. Pembuatan mikroenkapsulasi minyak ikan pada penelitain tersebut dengan menggunakan bahan penyalut berupa tepung daging, bungkil kelapa, dan menggunakan lesitin dari kedelai sebagai emulsifier. Proses pembuatan mikkroenkapsulasi minyak ikan dengan cara homogenisasi semua bahan kemudian dikeringkan dengan metode spray drying. Hasil mikroenkapsulasi minyak ikan pada penelitian tersebut memiliki 
kandungan ME sebesar $3691 \mathrm{KCal}$ dan protein sebesar 31,50\%. Hasil penelitian menunjukkan penambahan mikroenkapsul minyak ikan pada ransum broiler hingga taraf $2 \%$ dapat menurunkan kandungan kolesterol daging. Penurunan kandungan kolesterol pada daging tersebut disebabkan karena mikrokapsul minyak ikan dapat mencegah oksidasi dan mempertahankan kandungan asam lemak esensial omega 3. Sudibya, (1998) menjelaskan bahwa fungsi asam lemak omega-3 dalam menurunkan kandungan kolesterol melalui dua cara yaitu yang pertama merangsang ekskresi kolesterol melalui empedu dari hati ke dalam usus, dan yang kedua adalah dengan merangsang katabolisme kolesterol oleh High Density Lipoprotein (HDL) ke hati kembali menjadi asam empedu dan tidak diregenerasi lagi namun dikeluarkan bersama ekskreta. (Heldini, 2015) menambahkan bahwa ransum yang memiliki kandungan minyak ikan tinggi dapat meningkatkan waktu retensi pakan dalam usus halus serta memperpanjang laju aliran digesta pakan sehingga absorsi nutrien pakan lebih banyak.

(Malvin, 2017) melaporkan bahwa dengan penambahan 2\% mikroenkapsulasi minyak ikan pada pakan ayam broiler dapat meningkatkan produktivitas ayam broiler dengan cara meningkatkan pertambahan bobot badan dan menurunkan konversi pakan apabila dibandigkan dengan perlakuan kontrol dengan penambahan minyak ikan tanpa mikroenkapsulasi. Hasil tersebut disebabkan karena kandungan lemak yang tetap terjaga kualitasnya dalam pakan dapat meningkatkan ketersediaan dan kecernaan nutrien pakan dalam sistem pencernaan, sehingga berdampak pada peningkatan pencernaan dan penyerapan nutrien pakan, dan hasil akhirnya dapat meningkatkan pertambahan bobot badan pada ayam broiler. Konversi pakan dengan perlakuan mikroenkaspulasi juga memberikan hasil yang rendah apabila dibandingkan dengan perlakuan kontrol. Hal tersebut disebabkan karena dalam bentuk mikrokapsul, kualitas minyak ikan akan tetap terjaga dan terlindungi sehingga penggunaanya lebih efektif dan optimal, dan hasil akhirnya dapat mengoptimalkan pencernaan dan penyerapan nutrien pakan serta menghasilkan konversi pakan yang lebih rendah. Penambahan mikroenkapsulasi minyak ikan pada pakan ayam boriler dapat menghasilkan daging broiler yang tinggi omega 3. Tingginya kandungan asam lemak omega 3 juga mempengaruhi komposisi asam lemak tak jenuh lainnya seperti asam linoleat, asam oleat, palmitoleat, aracidonat, EPA, dan DHA.

(Sestilawarti, et al., 2013) melakukan penelitian dengan menambahkan mikroenkapsulasi minyak ikan dalam ransum puyuh. Pembuatan mikroenkapsulasi minyak ikan dalam penelitian tersebut dilakukan dengan menambahkan bahan penyalut dari tepung daging dan tulang serta bungkil kelapa kemudian dikeringkan dengan menggunakan metode spray drying. Hasil dari penelitian menjelaskan bahwa penambahan mikroenkapsulasi minyak ikan hingga $6 \%$ pada ransum puyuh tidak memberikan pengaruh yang signifikan pada performa produksi puyuh. Perlu dikaji lebih lanjut tentang pemanfaatan mikroenkapsulasi untuk puyuh, karena penelitian terkait topik tersebut masih belum banyak dilakukan sehingga sulit untuk mencari perbandingan penyebab tidak adanya perbedaan pada hasil penelitian.

Montesqrit (2007) juga melakukan penelitian terkait penambahan mikroekapsulasi minyak ikan untuk ayam petelur. Pembuatan mikroenkapsulasi minyak ikan dilakukan untuk melindungi minyak ikan dari oksidasi dan mengubahnya menjadi bentuk tepung untuk memudahkan dalam penanganan. Pembuatan mikroenkapsulasi minyak ikan menggunakan bahan penyalut dari bahan pakan seperti dedak gandum, dedak padi, jagung giling, corn gluten meal, bungkil kedelai, serta tepung daging dan tulang, menggnakan metode pengering drum dan spray drying. Hasil penelitian tersebut menunjukkan bahwa penambahan mikroenkapsulasi minyak ikan tidak memberikan pengaruh yang signifikan terhadap performa pertumbuhan ayam petelur dan juga kualitas telur, akan tetapi memberikan pengaruh yang signifikan terhadap peningkatan kandungan asam lemak omega 3 pada kuning telur, serta menurunkan kandungan kolesterol kuning telur dan serum darah. 


\section{KESIMPULAN}

Penggunaan mikroenkapsulasi minyak ikan dapat dilakukan dengan menggunakan metode spray drying dan menggunakan bahan pelapis maltodekstrin dan gum arab. Penambahan mikroenkapsulasi minyak ikan pada pakan dapat meningkatkan produktivias dan menurunkan kandungan kolesterol pada daging ayam broiler, serta meningkatkan kandungan asam lemak omega 3 dan menurunkan kandungan kolesterol pada kuning telur.

\section{UCAPAN TERIMAKASIH}

Artikel ini disusun sebagai bagian dari luaran pelaksanaan Program Kreativitas Mahasiswa bidang kegiatan Penelitain Eksakta (PKM-PE) tahun 2020. Untuk itu dalam kesempatan ini penulis mengucapkan terima kasih kepada Direktorat Pembelajaran dan Kemahasiswaan, Direktorat Jenderal Pendidikan Tinggi, Kementerian Pendidikan dan Kebudayaan, dan Kepada Politeknik Negeri Jember atas kesempatan serta dukungan dan bantuannya sehingga penulis dapat menyelesaikan penulisan artikel ilmiah ini.

\section{DAFTAR PUSTAKA}

Desmawarni. 2007. Pengaruh Komposisi Bahan Penyalut Dan Kondisi Spray Drying Terhadap Karakteristik Mikrokapsul Oleoresin Jahe. Skripsi. Departemen Teknologi Industri Pertanian Fakultas Teknologi Pertanian. Institut Pertanian Bogor.

Ellulu, M. S., Khaza'ai, H., Abed, Y., Rahmat, A., Ismail, P., \& Ranneh, Y. (2015). Role of fish oil in human health and possible mechanism to reduce the inflammation. Inflammopharmacology, 23(2-3), 79-89. https://doi.org/10.1007/s10787-015-0228-1

Hasibuan, N. E., Tamrin, \& Y. Muis. 2017. Mikroenkapsulasi minyak ikan pora-pora (Mystacoleucus padangensis) menggunakanmetode spray drying untuk aplikasi nutrisi makanan. Jurnal Kimia Mulawarman, 14(2), 108 - 114.

Heldini, A. (2015). Pengaruh penambahan minyak ikan tuna dalam ransum basal terhadap performan ayam broiler. Journal of Rural dan Development, 5(1), 69-84.

Hidayah, N. (2016). Perbandingan berbagai teknik mikroenkapsulasi pakan dalam menghasilkan daging sapi sehat. Seminar Nasional dan Gelar Produk, 143-151.

Idrus, S. (2013). Mikroenkapsulasi minyak ikan yang mengandung asam lemak omega-3 menggunakan gum arab sebagai bahan pelapis. Majalah Biam, 9(1), 23-29.

Jayanudin, J., Rochmadi, R., M. K. Renaldi, \& Pangihutan. (2017). Pengaruh bahan penyalut terhadap efisiensi enkapsulasi oleoresin jahe merah. ALCHEMY Jurnal Penelitian Kimia, 13(2), 275 - 287. https://doi.org/10.20961/alchemy.v13i2.5406

Kanakdande, D., Bhosale, R. \& Singhal, R.S. (2007). Stability cumin oleoresin microenkapsulated in different combination of gum arabic, maltodextrin, and modified starch. Carbohydrate Polymer 67, 536-541.

Khamidah, S. Z., Hastarini, E., Fardiaz, D., \& Budijanto, S. (2019). Mikroenkapsulasi konsentrat asam lemak tak jenuh dari minyak ikan patin. Jurnal Teknologi Dan Industri Pangan, 30(2), 143-151. https://doi.org/10.6066/itip.2019.30.2.143

Khasanah, U. L., B. K. Anandhito, T. Rachmawaty, R. Utami, \& G. J. Manuhara. (2015). Pengaruh rasio bahan penyalut maltodekstrin, gum arab, dan susu skim terhadap karakteristik fisik dan kimia mikrokapsul oleoresin daun kayu manis (Cinnamomum burmannii). Jurnal Agritech, 35(04), 414 - 421. https://doi.org/10.22146/agritech.9325

Kolanowski, W., M. Ziolkowski, J. Weißbrodt, B. Kunz, \& G. Laufenberg. 2005. Microencapsulation of fish oil by spray drying-impact on oxidative stability. Part 1. European Food Research and Technology. 
Madene A., M. Jacquot, J. Scher, \& S. Desobry. (2006). Flavour encapsulation and controlled release a review. Journal Food Science and Techology. 41, 1-21.

Malvin, T. (2017). Pengaruh pemberian mikrokapsul minyak ikan terhadap lemak abdomen dan kadar kolesterol daging broiler. Jurnal Penelitian Lumbung, 16(2), 45 - 54. https://doi.org/10.31227/osf.io/e4gkv

Mohammed, N. K., Tan, C. P., Manap, Y. A., Muhialdin, B. J., \& Hussin, A. S. M. (2020). Spray Drying for the Encapsulation of Oils-A Review. Molecules (Basel, Switzerland), 25(17), 1-16. https://doi.org/10.3390/molecules25173873

Montesqrit. (2007). Penggunaan Bahan Pakan Sebagai Bahan Penyalut Dalam Mikroenkapsulasi Minyak Ikan Lemuru Dan Pemanfaatannya Dalam Ransum Ayam Petelur. Disertasi Sekolah Pascasarjana Institut Pertanian Bogor. Bogor.

Nasrullah, F. (2010). Pengaruh Komposisi Bahan Pengapsul Terhadap Kualitas Mikrokapsul Oleoresing Lada Hitam (Piper ningrum L). Skripsi. Departemen Ilmu dan Teknologi Pangan. Fakultas Teknologi Pertanian Institut Pertanian Bogor, Bogor.

Nugraheni, A., N. Yunarto, \& N., Sulistyaningrum. (2015). Optimasi formula mikroenkapsulasi ekstrak rimpang temulawak (Curcuma xanthorrhiza Roxb.) dengan penyalut berbasis air. Jurnal Kefarmasian Indonesia, 5(2), 98-105.

Olive Li Y. (2009). Development Of Microencapsulation-Based Technologies For Micronutrient Fortification In Staple Foods For Developing Countries [Dissertation]. University of Toronto. Toronto.

Purnamayati, L., Dewi, E. N., \& Kurniasih, R. A. (2016). Karakteristik fisik mikrokapsul fikosianin spirulina pada konsentrasi bahan penyalut yang berbeda. Jurnal Teknologi Hasil Pertanian, 9(1), 1-8.

Sestilawarti, Mirzah, \& Montesqrit. (2013). Pengaruh pemberian mikroenkapsulasi minyak ikan dalam ransum puyuh terhadap performa produksi. Jurnal Peternakan Indonesia, 15(1), 69-74.

Sudibya. (1998). Suplementasi asam lemak PUFA dan precursor karnitin dalam ransum jagung kuning terfermentasi pengaruhnya terhadap komposisi kimiawi telur puyuh. Journal of Rural and Development, 4(2), 187 - 197.

Temiz, U. \& E. Öztürk. 2018. Encapsulation methods and use in animal nutrition. Selcuk Journal of Agriculture and Food Sciences, 32(3), 624-631. https://doi.org/10.15316/sjafs.

Wati, R.R., \& Sriwidodo, A. Y. C. (2020). Review teknik mikroenkapsulasi pada ekstrak Mangosteen. Journal of Current Pharmaceutical Sciences, 3(2), 241-248. 